hour loads for students and faculty. Yet today, Bologna terminology is rarely used in official documents or on university campuses. The law's article \# $\mathrm{I}$ of the new legislation defines an academic credit and the number of credits in a full-time academic year, creating norms that will facilitate international academic collaboration and enhance student mobility. Furthermore, the introduction of a PhD degree at Ukrainian universities significantly benefits global mobility of Ukrainian scholars, whose home status of "candidates of sciences" is not well-understood abroad. Global awareness of the "candidates of sciences" degree has been further muddied by a lack of clarity around the role of the Ukrainian Academy of Science, which had the exclusive right to grant these degrees. The process now will more closely mirror norms in other countries, including required courses, research, and dissertation defense in the presence of a university committee comprised of research field specialists.

\section{RESEARCH INTENSITY}

Global rankings, though increasingly under fire for overly limiting the definition of higher education excellence, remain an important component of the public face of a university. Those universities with good rankings and a strong reputation attract the best talent, whether in faculty, staff, or students. Thus, the quality of research and number of publications in reputable peer reviewed journals is increasingly important to the viability of an institution. Under the new law, Ukrainian universities are expected to intensify research capacity and production. Faculty, traditionally overloaded with more than 900-950 hours/year of classroom teaching, will see a decrease in their load to 600 hours/year. This is a significant change to free up academic staff for other scholarly pursuits, which can support the overall institutional goals, in particular for research and travel related to international research collaborations. These transformations pose a major shift to the status quo, and those that are slow to respond may find themselves quickly on the periphery and unable to access resources that are increasingly tied to international engagement.

\section{IMPACT OF INTERNATIONALIZATION}

Universities around the world struggle to respond to the demands and opportunities of globalization, thus the need for skilled change management is by no means a uniquely
Ukrainian problem. Universities tend toward hierarchical and bureaucratic self-organization and are notoriously resistant to change. The Ukrainian higher education system is perhaps starting at an earlier place than other countries where universities are freer to choose program content, make financial decisions, create degree granting and credit transfer policies, and hire faculty via open and transparent competition. In Ukraine, such innovations could be jeopardized if opposition causes delays to change, creating uncertainty, and lowering morale. On the positive side, there is much work already done on best practice for change management in higher education that could support Ukrainian universities to move through stages of change more quickly. The more accessible Ukrainian higher education can make itself to the world through internationalization, the more easily change will take root.

\section{CONCLUSION}

Successful implementation of these new reforms will prepare universities in Ukraine with tools to benefit from international opportunities. The effect of ongoing hostilities in the east of the country is challenging and may have unpredictable effects on the implementation and timing of specific reforms. A critical factor is the development of robust policies and processes, to manage the reforms in a fair and transparent manner to avoid backlash and further destabilization. Capacity building by those who have developed expertise in more decentralized systems-such as Ukrainian alumni who studied abroad, or other international experts will need to be engaged, to participate in the development of new processes-support new roles in educational administration and prepare a new cadre of education leaders with a progressive approach to education. Campus communities will need to be resilient, energetic, and optimistic to maintain the levels of motivation to impel change forward. Perhaps the motivation for Ukrainian higher education's commitment to educational reform is best summed up by Mykhaylo Zhurovskyi, Rector of the Kyiv National Technical University, and one of the authors of the new law who stated publicly that Ukraine has no other alternative but to begin to change its mentality and work hard to create a new country.

\section{NEW PUBLICATIONS}

Cantwell, Brendan, and Ilkka Kauppinen, eds. Academic Capitalism in the Age of Globalization. Baltimore: Johns Hopkins University Press, 2014. 277 pp. \$34.95 (pb).
ISBN 978-1-4214-1538-3. Web site: www. press.jhu.edu.

The idea of academic capitalism, which in general links neoliberal ideas with the growing marketization and privatization of higher education, was developed over the past two decades by Sheila Slaughter and her colleagues. This volume is based on the concepts of academic capitalism and provides case studies that used these concepts to analyze such themes as the historical development of universities, patents in the knowl- 
edge economy, the academic profession, in- Latvia, and others.

ternational student markets, and others.

Cheng, Ying, Qi Wang, and Nian Cai Liu, eds. How World-Class Universities Affect Global Higher Education: Influences and Responses. Rotterdam, Netherlands, Sense, 2014. 197 pp. \$54 (pb). ISBN 978-94-6209819-0. Web site: www.sensepublishers.com.

A collection of essays concerning the development of world-class universities globally, the focus of some of the chapters is on how these institutions affect the higher education system at large. Among the themes discussed are top-down excellence pressures in Russia, French efforts to improve the research universities, the excellence initiative in Germany, privatization and the transformation of world-class research universities, the dilemmas of middle-income countries, and others.

Eggins, Heather, ed. Divers and Barriers to Achieving Quality in Higher Education. Rotterdam, Netherlands, Sense, 2014. 181 pp. \$54 (pb). ISBN 978-94-6209-492-5. Web site: www.sensepublishers.com.

A series of 13 essays are broadly organized around themes of quality in higher education in a European context. Among the themes are the role of governance in influencing European standards for quality assurance, academic values and procedures of quality assurance, quality management concepts, the development of a quality culture in
Fish, Stanley. Visions of Academic Freedom: From Professionalism to Revolution. Chicago: University of Chicago, 2014. 164 pp. \$24 (hb). ISBN 978-0-266-06431-4. Web site: www.press.uchicago.edu.

Fish, a well-known analyst of American society, posits five key approaches to academic freedom in the American context, and discusses these as ways of defining and defending academic freedom.

Kehm, Barbara M., and Ulrich Teichler, eds. The Academic Profession in Europe: New Tasks and New Challenges. Dordrecht, Netherlands: Springer, 2013. 200 pp. \$129 (hb). ISBN 978-94-007-4613-8. Web site: www. springer.com.

A volume in the Changing Academic Profession series, this book focuses on the European countries included in the CAP surveys. All of the chapters are comparative in nature. Among the themes discussed are professional identity, the changing role of the academic profession in the context of managerialism, the view of academics concerning governance, relevance, and satisfaction, academic markets and careers, views about the "third mission" of universities, and others.

Lane, Jason, ed. Building a Smarter University: Big Data, Innovation, and Analytics. Albany, NY: State University of New York Press, 2014. 317 pp. \$29.95 (pb). ISBN 978-1-4384-
5452-8. Web site: www.sunypress.edu.

The idea of the "Big Data" movement in American higher education is to use data from many sources to solve key academic problems and make the best possible academic decisions. The movement also encourages universities to collect data with the goal of using it to solve problems. This volume includes discussions of such themes as legal issues related to big data, college admissions strategies, data-driven innovations to assist in student success, human capital development, and others.

Menon, Maria Eliophotou, Dawn Geronimo Terkla, and Paul Gibbs, eds. Using Data to Improve Higher Education. Rotterdam, Netherlands: Sense, 2014. 256 pp. \$54 (pb). ISBN 978-94-6209-792-6. Web site: www. sensepublishers.com.

This book is based on the idea that the collection of careful and useful data will be valuable in decision making for higher education institutions and systems. Internal data are typically collected by institutional research departments in universities, but are often not effectively used. The chapters in this book focus on such themes as student feedback data, the evaluation of student academic life, the returns to investment in higher education, and others. Chapters also deal with several case studies relating to the use of data, and also to the ethical and quality issues relating to data usage.

\section{New BoOKS fROM CIHE}

In cooperation with the American Council on Education (ACE), Global Opportunities and Challenges for Higher Education Leaders: Briefs on Key Themes, has recently been released. This volume is part of CIHE's ongoing collaboration with ACE on a series of essays and webinars concerning key higher education themes. Further information concerning this book can be obtained from Sense Publishers (www. sensepublishers.com).

We have also just published (with Lemmens Media) Higher Education: A Worldwide Inventory of Research Centers,
Academic Programs, and Journals and Publications (3rd Edition). Two versions of the book are available-full-length (358 pages) and abridged ( 80 pages). The full-length e-book is available for purchase $\left(€_{\mathrm{I} 2}\right)$ from Amazon.com. A fulllength version of the book is also available in PDF format $\left(€_{\mathrm{I}} 8\right)$ directly from Lemmens (info@lemmens.de). Finally, the abridged version of the book may be purchased as a hard copy, plus a free PDF (€28); again, see info@lemmens.de. 